\title{
PENERAPAN MODEL CONTEXTUAL TEACHING AND LEARNING UNTUK MENINGKATKAN MOTIVASI SISWA DI KELAS VII SMPN 30 MUARO JAMBI
}

Atika Hapizoh ${ }^{1}$, Jufrida ${ }^{2}$, dan Darmaji ${ }^{3}$

1,2,3 Program Studi Pendidikan Fisika FKIP Universitas Jambi, Jambi, Indonesia

Corresponding author email: atika9889@gmail.com

Info Artikel

Diterima:

17 Juli 2019

Disetujui:

19 Mei 2020

Dipublikasikan:

30 Juni 2020

\begin{abstract}
Abstrak:
Penelitian ini dilatar belakangi oleh rendahnya motivasi belajar fisika siswa di SMPN 30 Muaro Jambi. Dengan menggunakan model pembelajaran Contextual Teaching and Learning (CTL) diharapkan siswa akan lebih mudah memahami pembelajaran dan menerima ilmu pengetahuan secera efektif dan efisien. Sehingga, dapat meningkatkan motivasi belajar siswa, dikarenaka pada materi suhu dan perubahannya berisikan uraian materi yang bersifat konsep dan hitungan, maka dalam penyajian materi ini diperlukan model pembelajaran yang dapat mendorong motivasi belajar siswa. Dari hasil penelitian, dapat dilihat bahwa terjadi peningkatan motivasi belajar siswa dari siklus I yaitu $59,74 \%$ menjadi $72,18 \%$ pada siklus II dan $82,61 \%$ pada siklus III. Dengan demikian dapat disimpulkan bahwa penerapan model pembelajaran Contextual Teaching and Learning (CTL) dapat meningkatkan motivasi belajar siswa di kelas VII B SMPN 30 Muaro Jambi.
\end{abstract}

Kata kunci: Contextual teaching and learning, motivasi belajar.

\begin{abstract}
:
This research was motivated by low of motivation to learn physics at SMPN 30 Muaro Jambi. By using the Contextual Teaching and Learning (CTL) learning model, it is expected that students will more easily to understand and receive knowledge effectively and efficiently. So, it can increase student learning motivation, because the temperature material and its changes contain a description of the material that is conceptual and quantitative, so in presenting this material a learning model is needed to encourage student learning motivation. From the results, it can be seen that there is an increase in learning motivation experienced by students from the first cycle $59.74 \%$ to $72.18 \%$ in cycle II and $82.61 \%$ in cycle III. Thus it can be concluded that the application of the Contextual Teaching and Learning (CTL) learning model can increase student motivation in class VII B SMPN 30 Muaro Jambi.
\end{abstract}

Keywords: Contextual teaching and learning, learning motivation. 


\section{Pendahuluan}

Pendidikan merupakan unsur utama dalam pengembangan manusia Indonesia seutuhnya. Oleh karenanya, pengelolaan pendidikan harus berorientasi kepada bagaimana menciptakan perubahan yang lebih baik. Salah satu upaya mengatasi hal tersebut ditempuh dengan menerapkan kurikulum 2013 yang disusun dengan dilandasi pemikiran tentang masa depan, yaitu tantangan abad ke-21 yang ditandai dengan abad ilmu pengetahuan, knowledge-based society dan kompetensi masa depan. Pembelajaran dalam konteks kurikulum 2013 diarahkan untuk berbasis pada aktivitas belajar siswa dibawah bimbingan, motivasi dan arahan guru. Selain hal tersebut, untuk menghadapi kurikulum 2013 juga diperlukan suatu kegiatan pembelajaran student center bukan teacher center yang diaplikasikan melalui pembelajaran scientific yang menuntut siswa untuk bekerja aktif secara ilmiah dalam menyelesaikan suatu masalah atau suatu materi yang diajarkan.

Pelajaran fisika termasuk salah satu mata pelajaran yang kurang disukai oleh kebanyakan siswa. Pada umumnya, siswa menemukan banyak kesulitan dalam belajar fisika sehingga banyak siswa yang memiliki prestasi belajar fisika yang rendah. Prestasi belajar dipengaruhi oleh beberapa faktor, baik faktor dari dalam (faktor internal) maupun faktor dari luar (faktor eksternal). Menurut Suryabrata (Ekawarna 2009), yang termasuk faktor internal adalah faktor fisiologis dan faktor psikologis (misalnya motivasi berprestasi, kecerdasan dan kemampuan kognitif), sedangkan faktor eksternal adalah faktor lingkungan dan faktor instrumental (misalnya guru, kurikulum dan model pembelajaran).

Pendekatan kontekstual (CTL) merupakan konsep belajar yang beranggapan bahwa anak akan belajar lebih baik jika lingkungan diciptakan secara alamiah, artinya belajar akan lebih bermakna jika anak "bekerja" dan "mengalami" sendiri apa yang dipelajarinya bukan sekedar "mengetahuinya". Pembelajaran tidak sekedar kegiatan mentransfer pengetahuan dari guru kepada siswa, tetapi bagaimana siswa mampu memaknai apa yang dipelajari itu. Oleh karena itu, strategi pembelajaran lebih utama daripada hasil. Dalam hal ini siswa perlu mengerti apa makna belajar, apa manfaatnya, dalam status apa mereka, dan bagaimana mencapainya (Katrin, 2015).

Penelitian ini dilatar belakangi oleh rendahnya motivasi belajar fisika siswa di SMPN 30 Muaro Jambi. Dengan menggunakan model pembelajaran Contextual Teaching and Learning (CTL) diharapkan siswa akan lebih mudah memahami pembelajararan dan menerima ilmu pengetahuan secera efektif dan afisien. Sehingga, dapat meningkatkan motivasi belajar siswa, dikarenakan pada materi suhu dan perubahannya berisikan uraian materi yang bersifat konsep dan hitungan, maka dalam penyajian materi ini diperlukan model pembelajaran yang dapat mendorong motivasi belajar siswa. Model pembelajaran sangat penting bagi siswa karena minat dan perhatian dapat meningkatkan interaksi siswa dengan guru. Materi yang diajarkanpun harus disesuaikan dengan masalah-masalah yang dihadapi oleh siswa agar siswa dapat dengan mudah memahami dan menerapkannya dalam kehidupan sehari-hari. Model pembelajaran yang dapat diterapkan guru untuk mengatasi permasalahan- permasalahan di atas adalah model pembelajaran yang dapat meningkatkan motivasi belajar siswa salah satunya adalah model pembelajaran Contextual Teaching and Learning (CTL).

Menurut Ngalimun (2016:230) ada tujuh indikator yang terdapat pada model pembelajaran Contextual Teaching and Learning (CTL) yaitu modeling (pemusatan perhatian, motivasi, penyampaian kompetensi-tujuan, pengarahan-petunjuk, rambu-rambu, contoh), questioning (eksplorasi, membimbing, menuntun, mengarahkan, mengembangkan, evaluasi, inkuiri, generalisasi), learning community (seluruh siswa partisipatif dalam belajar kelompok atau individual, minds-on, hands-on, mencoba, mengerjakan), inquiry (identifikasi, investigasi, hipotesis, konjektur, generalisasi, menemukan), constructivism (membangun pemahaman sendiri, mengkonstruksi konsep- aturan, analisis-sintesis), reflection (review, rangkuman, tindak lanjut), authentic assessment (penilaian selama proses dan sesudah pembelajaran, penilaian terhadap setiap aktivitas-usaha siswa, penilaian potofolio, penilaian subjektif-objektifnya dari berbagai aspek dengan berbagai cara). Berdasarkan uraian di atas, penulis tertarik untuk melakukan penelitian mengenai "Penerapan Model Pembelajaran Contextual Teaching and Learning (CTL) Untuk Meningkatkan Motivasi Belajar Siswa di Kelas VII SMPN 30 Muaro Jambi”. 


\section{Metode Penelitian}

Jenis penelitian ini adalah Penelitian Tindakan Kelas(Classroom Action Research). Tempat yang digunakan untuk penelitian adalah SMPN 30 Muaro Jambi. Penelitian ini dilaksanakan di kelas VII B SMPN 30 Muaro Jambi pada semester ganjil tahun pelajaran 2017/2018. Subyek penelitian ini adalah siswa di kelas VII B SMPN 30 Muaro Jambi, dijadikan subjek penelitian karena prestasi belajarnya yang rendah dikarenakan motivasi belajarnya juga rendah. Penelitian ini dilaksanakan dalam tiga siklus, terdiri dari siklus I, siklus II dan siklusIII. Dalam penelitian ini peneliti bekerjasama dengan guru bidang studi fisika yang mengajar di kelas VII B. Pada setiap siklus memiliki tahapan-tahapan tertentu sesuai dengan tahapan dalam tindakan kelas yang dikemukakan oleh Sukardi (2013). Tahapan-tahapan yang dimaksud adalah:

\section{Perencanaan (Planning)}

Pada tahap ini peneliti membuat rencana pembelajaran, mempersiapkan alat-alat pendukung yang diperlukan di kelas sesuai dengan rencana pembelajaran, membuat lembar observasi aktivitas siswa, membuat lembar observasi pelaksanaan pembelajaran, menyiapkan lembar kerja siswa (LKS) dan merancang alat evaluasi berupa soal tes dan kunci jawaban.

\section{Tindakan (Action)}

Setelah semua persiapan perencanaan selesai, maka langkah selanjutnya adalah pelaksanaan tindakan. Pelaksaan tindakan pada tiap siklus dilakukan dalam 2 kali pertemuan. Tindakan dalam penelitian ini dilakukan dalam 3 siklus. Pada setiap siklus akan dilakukan observasi terhadap guru dan siswa. Setiap siklus juga diakhiri dengan kegiatan penyebaran angket motivasi untuk mengetahui motivasi belajar siswa. Proses pembelajaran dilakukan sesuai dengan jadwal pelajaran fisika kelas VIIB dan rencana pembelajaran yang telah disiapkan.

\section{Pengamatan (Observation) dan Evaluasi}

Pada tahap ini dilakukan pengamatan terhadap pelaksanaan tindakan dengan menggunakan lembar observasi yang telah disediakan yaitu lembar observasi guru dengan pedoman penskoran observasi guru dan lembar observasi siswa yang telah disesuaikan dengan menggunakan model pembelajaran Contextual Teaching and Learning (CTL). Pada setiap akhir siklus dilaksanakannya pengisian angket motivasi belajar siswa.

\section{Refleksi (Reflecting)}

Dari hasil observasi yang dilakukan, maka tahapan selanjutnya adalah melakukan refleksi. Hasil refleksi akan menentukan apakah tindakan yang dilakukan dapat memecahkan masalah, jika hasilnya belum seperti yang diharapkan, atau masalah yang ada belum terselesaikan maka dilakukan perbaikan pada siklus berikutnya. Pada tahap ini peneliti melakukan evaluasi dari pelaksanaan tindakan pada siklus I yang digunakan sebagai bahan pertimbangan perencanaan pembelajaran siklus berikutnya. Tahapan ini bertujuan untuk meningkatkan tindakan yang masih kurang dan harus lebih diperhatikan untuk disempurnakan pada siklus berikutnya.

Jenis data yang diambil dalam penelitian ini adalah Data Kualitatif yaitu data tentang aktivitas siwa dan pelaksanaan pembelajaran dalam proses belajar mengajar.

Intrumen Penelitian

Lembar observasi siswa digunakan sebagai instrumen untuk mengetahui keaktifan siswa dalam proses pembelajaran.Lembar observasi pelaksanaan pembelajaran Lembar observasi pelaksanaan pembelajaran ini digunakan sebagai instrumen untuk mengetahui kemampuan guru dalam menerapkan model pembelajaran contextual teaching and learning (CTL) pada proses pembelajaran. Angket digunakan sebagai instrumen untuk mengetahui motivasi siswa dalam proses pembelajaran. 
Teknik pengumpulan Data

Cara yang dilakukan dalam pengumpulan data pada penelitian ini adalah:

1. Data aktivitas belajar siswa diambil dari lembar observasi siswa yang dilakukan oleh pengamat saat melaksanakan penelitian

2. Data kegiatan guru diambil dari lembar observasi guru yang dilakukan pengamat saat melaksanakan penelitian

3. Data motivasi belajar siswa diambil melalui angket motivasi yang diberikan kepada siswa pada saat melaksanakan penelitian

4. Dokumentasi pelaksanaan pembelajaran berupa foto dan video.

Teknik Analisis Data

1. Analisis Motivasi Siswa dalam Belajar Untuk mendeskripsikanmotivasi

belajar fisika pada materi usaha dan perubahannya dalam lembar angket digunakan rumus :

$$
\begin{gathered}
\text { Rata }- \text { rata tiap indikator }=\frac{\text { Jumlah skor tiap indikator }}{\text { Jumlah seluruh siswa }} \\
\text { Persentase rata }- \text { rata tiap indikator }=\frac{\text { Jumlah skor tiap indikator }}{\text { Jumlah seluruh siswa }} \times 100 \%
\end{gathered}
$$

Hasil perhitungan tersebut dapat diberikan arti sebagai berikut:

$81 \%-100 \% \quad$ : Motivasi Belajar Sangat tinggi

$61 \%-80 \% \quad:$ Motivasi BelajarTinggi

41\%-60\% : Motivasi Belajar Sedang

21\%-40\% : Motivasi Belajar Rendah

0\%-20\% : Motivasi Belajar Sangat rendah

1. Hasil Observasi

a. Menghitung hasil observasiguru

Penskoran untuk skala penilaian dan kriteria penilaian yang digunakan lembar observasi terhadap aktivitas guru pada penelitian ini adalah sebagai berikut:

Skor 1 tidak dilakukan

Skor 2 kurang

Skor 3 cukup

Skor 4 baik

Skor 5 baik sekali

Data yang diperoleh berupa skor kemudian dihitung nilainya menggunakan rumus :

$$
\text { Persentase }=\frac{\text { Total skor yang dilakukan tiap siklus }}{\text { Skor maksimum }} \times 100 \%
$$

Kriteria penilaian:

$$
\begin{array}{ll}
0 \% \text { < rata-rata } & \leq 20 \%=\text { Kinerja Guru SangatKurang } \\
20 \% \text { <rata-rata } & \leq 40 \%=\text { KinerjaGuruKurang } \\
40 \% \text { <rata-rata } & \leq 60 \%=\text { Kinerja Guru Cukup } \\
60 \% \text { <rata-rata } & \leq 80 \%=\text { KinerjaGuruBaik }
\end{array}
$$


$80 \%$ <rata-rata $\leq 100 \%=$ Kinerja Guru SangatBaik

b. Menghitung hasil observasi siswa

$$
\text { Persentase aktivitas }=\frac{\text { Jumlah siswa yang aktif }}{\text { Jumlah seluruh siswa }} \times 100 \%
$$

Penilaian terhadap aktivitas siswa digunakan dengan menggunakan rumus:

Kriteria penilaian :

$$
\begin{aligned}
& 0 \% \leq \text { rata-rata } \leq 20 \%=\text { Tidak Aktif } \\
& 20 \%<\text { rata-rata } \leq 40 \%=\text { Kurang Aktif } \\
& 40 \%<\text { rata-rata } \leq 60 \%=\text { Cukup Aktif } \\
& 60 \%<\text { rata-rata } \leq 80 \%=\text { Aktif } \\
& 80 \%<\text { rata-rata } \leq 100 \%=\text { SangatAktif }
\end{aligned}
$$

\section{Hasil Penelitian dan Pembahasan}

Dari hasil penelitian, dapat dilihat bahwa terjadi peningkatan terhadap motivasi belajar yang dialami siswa dari pra siklus yaitu 50,54 \%, menjadi 59,74 \% pada siklus I dan menjadi $72,18 \%$ pada siklus II dan $82,61 \%$ pada siklus III. Dengan demikian dapat disimpulkan bahwa penerapan model

\begin{tabular}{|c|c|c|c|c|c|}
\hline \multirow{2}{*}{ No } & \multirow{2}{*}{$\begin{array}{l}\text { Indikator motivasi yang } \\
\text { Diamati }\end{array}$} & \multicolumn{4}{|c|}{ Persentase } \\
\hline & & $\begin{array}{l}\text { Pra } \\
\text { Siklus }\end{array}$ & Siklus I & Siklus II & Siklus III \\
\hline 1 & Aktivitas belajar tinggi & $43 \%$ & $50 \%$ & $53,6 \%$ & $69,4 \%$ \\
\hline 2 & Tekun dalam mengerjakan tugas & & & & \\
\hline 3 & Ulet dalam menohadani kesulitan & $45,6 \%$ & $55,04 \%$ & $69,12 \%$ & $75,84 \%$ \\
\hline 4 & Adanya informasi dari Guru & $44 \%$ & $54,67 \%$ & $64,8 \%$ & $73,6 \%$ \\
\hline 5 & Adanya umpan balik & $44,6 \%$ & $51,6 \%$ & $64,6 \%$ & $75,2 \%$ \\
\hline 6 & Adanya penguatan & $46,2 \%$ & $54 \%$ & $64,4 \%$ & $70,4 \%$ \\
\hline & Rata-rata & $4,46 \%$ & $52,64 \%$ & $63,34 \%$ & $71,91 \%$ \\
\hline
\end{tabular}
pembelajaran Contextual Teacing and Learning (CTL) dapat meningkatkan motivasi belajar siswa di kelas VIIB SMPN 30 MuaroJambi. Gambaran mengenai peningkatan motivasi belajar siswa yang diperoleh dari penerapan model pembelajaran Contextual Teaching and Learning (CTL) dapat dilihat pada tabel berikut ini :

Tabel 1. Peningkatan Motivasi Belajar Siswa Tiap Indikator

Dari tabel di atas dapat dilihat pada pelaksanaan tindakan siklus I rata-rata motivasi belajar siswa masih berada pada kategori kurang, selanjutnya pada siklus II meningkat pada kategori cukup dan pada siklus III rata- rata motivasi belajar siswa meningkat menjadi baik. Sehingga dapat disimpulkan bahwa setiap siklus terdapat peningkatan motivasi belajar siswa yang semakin baik. Hal ini menunjukkan bahwa penerapan model pembelajaran Contextual Teaching and Learning (CTL) dalam proses pembelajaran Fisika dapat meningkatkan motivasi belajar siswa.

Dapat disimpulkan, bahwa aktivitas siswa dalam penelitian ini juga mengalami peningkatan sesuai dengan langkah-langkah model pembelajaran Contextual Teaching and Learning (CTL). Aktivitas ini dapat meningkat karena aktivitas yang dilakukan oleh guru selalu diperbaiki berdasarkan Penerapan Model Contextual.... (Atika Hapizoh, dkk) hal:45-51 
kendala dan solusi yang ada pada setiap siklus agar siswa dapat termotivasi untuk mengikuti pembelajaran.

Berdasarkan hasil penelitian, dapat disimpulkan bahwa pelaksanaan pembelajaran dengan menerapkan model pembelajaran Contextual Teaching and Learning (CTL) dapat meningkatkan motivasi belajar fisika siswa pada materi suhu dan perubahannya di SMPN 30 MuaroJambi.

\section{Simpulan}

Tindakan kelas yang telah dilaksanakan dengan menerapkan model pembelajaran Contextual Teaching and Learning (CTL) dapat meningkatkan motivasi belajar siswa,hal ini dapat dilihat dari rata-rata presentase motivasi belajar siswa pada pra siklus adalah $50,54 \%$, siklus I adalah $59,74 \%$, siklus II $72,18 \%$, dan siklus III $82,61 \%$. Indikator motivasi belajar siswa yang meningkat diantaranya adalah aktivitas belajar yang tinggi, tekun dalam mengerjakan tugas, ulet dalam menghadapi kesulitan, adanya informasi dari guru, adanya umpan balik dan adanya penguatan.

\section{Referensi}

Andes. (2016). Penerapan Model Contextual Teaching and Learning (CTL) untukMeningatkanMotivasiBelajarSiswaKelas IV SDN Sekelimus. UniversitasPasundan. Bandung

Andipa (2016). Bab 4 Suhu dan Perubahannya. Dikutip 7 September 2017 dari Materi Pandi IPA:http//materiipaandipa.blogspot.com/201 6/10/bab-4-suhu-dan- perubahannya.html?m=1

Arikunto, Suharsimi dkk. (2013). Dasar-Dasar Evaluasi Pendidikan. Jakarta: BumiAksara.

Aris, Shoimin. (2014). 68 Model Pembelajaran InovatifdalamKurikulum 2013.Yogyakarta: Ar-Ruzz Media

Aunurrahman, (2012).BelajardanPembelajaran.Bandung: Alfabeta Biantirusmayani212. 2017. SuhudanPerubahannya. Dikutip 7 September 2017 dari Bianti rusmayani 212: http//biantirusmayani212.blogspot.com/ 2017/03/materi-ipa-terpadu-kelas-7- smp-suhudan.html?m=1

Dimyati dan Mudjiono. (2010). Belajar dan Pembelajaran. Jakarta: RinekaCipta.

Ekawarna. (2009). Penelitian TindakanKelas.Jakarta: Gaung Persada.

Hamalik, Oemar. (2013). Proses Belajar Mengajar. Jakarta: Bumi Aksara.

Hartini, Nanik. (2010). Penerapan Model Pembelajaran Contextual Teaching and Learning (CTL) untuk Meningatkan Motivasi Belajar IPA Siswa Kelas II SDN 02 Gambirmanis Pracimantoro Wonogiri Tahun Ajaran 2009/2010.Universitas Sebelas Maret. Surakarta.

Huda Miftahul. (2014). Model-Model Pengajaran dan Pembelajaran. Yogyakarta: Pustaka Pelajar

Katrin, Septina. (2015). Penggunaan Model Pembelajaran Contextual Teaching and Learning (CTL) Untuk Meningatkan Motivasi Belajar PKN Siswa Kelas VI SDN 42 Duri Barat Kecamatan Mandau Kabupaten Bengkalis. Jurnal PPKn dan Hukum. 10. 1-21.

Kementerian Pendidikan dan Kebudayaan.(2016). Ilmu Pengetehuan Alam. Jakarta : Kementerian Pendidikan dan Kebudayaan.IPA7.

Ngalimun. (2013). Strategi dan Model Pembelajaran. Yogyakarta: Aswaja Pressindo.

Prihantini, Esti. 2013. Penerapan Model Pembelajaran Kontektual Untuk Meningatkan Motivasi dan Hasil Belajar Siswa Kelas VIII di SMP Taman Siswa Gedongtataan. Universitas Lampung.Bandar Lampung. 
Riki, Herkulanus. (2016). PenerapanPembelajaranContextual Teaching and Learning (CTL) UntukMeningatkanMotivasiBelajarSiswaKelas VIIIAStudiKasus di SMP Pangudi Luhur Salatiga. Universitas Kristen Satya Wacana. Salatiga.

Rosyidah, Umi. (2009). Penerapan Model Pembelajaran Contextual Teaching and Learning (CTL) untuk meningatkan motivasi dan Keaktifan siswa kelas VII SMP 3 Karanganyar. Universitas Sebelas Maret. Surakarta.

Rusman. (2014). Model-Model Pembelajaran.Jakarta: PT Raja Grafindo Persada

Sadia, Wayan I, (2014). Model-Model Pembelajaran Sains Kontruktivistik. Yogyakarta: Graha Ilmu.

Sagala, Syaiful. (2006). Konsep dan Makna Pembelajaran. Bandung: Alfabeta.

Sardiman. (2011). Interaksi dan Motivasi Belajar Mengajar. Jakarta: Rajagrafindo Persada.

Slameto. (2013). Belajar dan Faktor-faktor yang Mempengaruhinya. Jakarta: Rineka Cipta.

Sudjana, Nana. (2009). Penilaian Hasil Proses Belajar Mengajar. Bandung: Remaja Rosdakarya.

Sugihartono, dkk. (2007). Psikologi Pendidikan. Yogyakarta: UNY Press.

Sukardi, Prof. (2013). Metode Penelitian Tindakan Kelas, Implementasi dan Pengembangannya. Jakarta: PT. Bumi Aksara

Taniredja Tukiran dkk. (2013). Model-Model Pembelajaran Inivatif dan Efektif. Bandung: Alfabeta

Wahidmurni, dkk. (2010). Evaluasi Pembelajaran Kompetensi dan Praktik. Yogyakarta: NuhaLitera. 